\title{
Are radiogallium-labelled DOTA-conjugated somatostatin analogues superior to those labelled with other radiometals?
}

\author{
P. Antunes $\cdot$ M. Ginj $\cdot$ H. Zhang $\cdot$ B. Waser $\cdot$ \\ R. P. Baum • J. C. Reubi $\cdot$ H. Maecke
}

Received: 13 July 2006 / Accepted: 5 November 2006 / Published online: 16 January 2007

(C) Springer-Verlag 2007

\begin{abstract}
Purpose Gallium-68 is a metallic positron emitter with a half-life of $68 \mathrm{~min}$ that is ideal for the in vivo use of small molecules, such as $\left[{ }^{68} \mathrm{Ga}\right.$-DOTA, $\left.\mathrm{Tyr}^{3}\right]$ octreotide, in the diagnostic imaging of somatostatin receptor-positive tumours. In preclinical studies it has shown a striking superiority over its ${ }^{111}$ In-labelled congener. The purpose of this study was to evaluate whether third-generation somatostatin-based, radiogallium-labelled peptides show the same superiority.

Methods Peptides were synthesised on solid phase. The receptor affinity was determined by in vitro receptor autoradiography. The internalisation rate was studied in AR4-2J and hsst-HEK-transfected cell lines. The pharmacokinetics was studied in a rat xenograft tumour model, AR4-2J.

Results All peptides showed high affinities on hsst2, with the highest affinity for the $\mathrm{Ga}^{\mathrm{III}}$-complexed peptides. On hsst3 the situation was reversed, with a trend towards lower affinity of the $\mathrm{Ga}^{\mathrm{III}}$ peptides. A significantly increased internalisation rate was found in sst2-expressing cells for all

${ }^{67} \mathrm{Ga}$-labelled peptides. Internalisation into HEK-sst3 was
\end{abstract}

P. Antunes $\cdot$ M. Ginj $\cdot H$. Zhang $\cdot H$. Maecke $(\bowtie)$

Division of Radiological Chemistry, University Hospital Basel,

Petersgraben 4,

4031 Basel, Switzerland

e-mail: hmaecke@uhbs.ch

B. Waser · J. C. Reubi

Institute of Pathology, University of Bern,

Bern, Switzerland

R. P. Baum

Department of Nuclear Medicine/PETCT-Center,

Zentralklinik Bad Berka,

Bad Berka, Germany usually faster for the ${ }^{111}$ In-labelled peptides. No internalisation was found into sst5. Biodistribution studies employing $\left[{ }^{67} \mathrm{Ga}-\mathrm{DOTA}, 1-\mathrm{Nal}^{3}\right]$ octreotide in comparison to $\left[{ }^{111} \mathrm{In}\right.$-DOTA, $\left.1-\mathrm{Nal}^{3}\right]$ octreotide and $\left[{ }^{67} \mathrm{Ga}-\mathrm{DOTA}, \mathrm{Tyr}^{3}\right]$ octreotide showed a significantly higher and receptormediated uptake of the two ${ }^{67} \mathrm{Ga}$-labelled peptides in the tumour and somatostatin receptor-positive tissues. A patient study illustrated the potential advantage of a broad receptor subtype profile radiopeptide over a high-affinity sst2selective radiopeptide.

Conclusion This study demonstrates that ${ }^{67 / 68}$ Ga-DOTAoctapeptides show distinctly better preclinical, pharmacological performances than the ${ }^{111}$ In-labelled peptides, especially on sst2-expressing cells and the corresponding animal models. They may be excellent candidates for further development for clinical studies.

Keywords Somatostatin receptors · Gallium-68 · Indium-111 $\cdot$ Radiopeptides $\cdot$ Imaging

\section{Introduction}

Peptide receptors with high overexpression on a variety of human tumours are a focus of research in radiopharmacy and nuclear oncology. The prototype is the somatostatin receptor, which has been found to be overexpressed not only on neuroendocrine tumours but also on renal cell carcinoma, small cell lung cancer, breast cancer, prostate cancer and malignant lymphoma [1]. Somatostatin analogues have been radiolabelled with diagnostic radionuclides for imaging and tumour localisation as well as with particle emitters for targeted radionuclide therapy. Labelling has been performed with the $\gamma$-emitters ${ }^{99 \mathrm{~m}} \mathrm{Tc}[2-4],{ }^{111} \mathrm{In}$ $[5,6]$ and ${ }^{67} \mathrm{Ga}$ [7], with the positron emitters ${ }^{11} \mathrm{C}[8],{ }^{18} \mathrm{~F}$ 
[9] and ${ }^{64} \mathrm{Cu}$ [10], and with particle emitters such as ${ }^{90} \mathrm{Y}$ [11-14], ${ }^{177} \mathrm{Lu}[15]$ and ${ }^{213} \mathrm{Bi}$ [16]. [ $\left.{ }^{111} \mathrm{In}-\mathrm{DTPA}\right]-$ octreotide (Octreoscan) is the first registered radiopeptide and currently the most sensitive method for staging of neuroendocrine tumours [17].

Currently, the metallic positron emitter ${ }^{68} \mathrm{Ga}$ is of great interest [18] because of its suitable radiophysical properties; its positron yield is high, with $89 \%$ of all disintegrations. Its half-life of $68 \mathrm{~min}$ matches the pharmacokinetics of many peptides and other small molecules owing to a fast blood clearance, quick diffusion and target localisation. In addition, and of major importance, is the fact that it can be produced from a ${ }^{68} \mathrm{Ge} /{ }^{68} \mathrm{Ga}$ generator. Especially attractive is the long half-life of 270.8 days of the parent ${ }^{68} \mathrm{Ge}$, which allows use of the generator for up to 1 year or even longer. A version of this generator is now commercially available, and this is strongly motivating radiopharmacists to develop new radiogallium-based radiopharmaceuticals.

We have been interested in designing peptide-chelator conjugates for labelling with ${ }^{67,68} \mathrm{Ga}$, in particular those based on somatostatin analogues. We used and compared different chelators such as desferrioxamine [7], NOTAGA (1,4,7-triazacyclononane,1-glutaric acid, 4,7-acetic acid) [19] and DOTA (1,4,7,10-tetraazacyclododecane, 1,4,7,10tetraacetic acid) [20, 21]. Interestingly, when DOTA was coupled to the octapeptide $\left[\mathrm{Tyr}^{3}\right]$ octreotide, the resulting $\left[{ }^{67} \mathrm{Ga}\right.$-DOTA,Tyr $\left.{ }^{3}\right]$ octreotide ([ ${ }^{67} \mathrm{Ga}$-DOTA $]$-TOC) showed not only about a fivefold increased affinity to the somatostatin receptor subtype 2 (sst2) but also a 2.5 -fold increased tumour uptake compared with $\left[{ }^{111}\right.$ In-DOTA]TOC in a mouse xenograft model (AR4-2J). In addition, the kidney uptake of $\left[{ }^{67} \mathrm{Ga}\right.$-DOTA $]-T O C$ was distinctly decreased compared with that of $\left[{ }^{111}\right.$ In-DOTA]-TOC or $\left[{ }^{90}\right.$ Y-DOTA $]$-TOC $[20,21]$. These very promising preclinical data prompted several research groups to study [ ${ }^{68} \mathrm{Ga}-$ DOTA]-TOC in patients with somatostatin receptor-positive tumours [22-27]. The Bad Berka group has almost 2 years' experience employing ${ }^{68} \mathrm{Ga}$-DOTA-octapeptides in a variety of somatostatin receptor-positive tumour patients, mainly gastroenteropancreatic (GEP) tumours $[28,29]$. In addition, first promising results have been reported [30, 31] using $\left[{ }^{68} \mathrm{Ga}\right.$-DOTA, $\left.1-\mathrm{Nal}^{3}\right]$ octreotide $\left(\left[{ }^{68} \mathrm{Ga}\right.\right.$-DOTA $]$-NOC) receptor $\mathrm{PET} / \mathrm{CT}$ in patients before and after peptide receptor radionuclide therapy (PRRT). Furthermore, $\left[{ }^{68} \mathrm{Ga}\right.$-DOTA, $\left.\mathrm{Tyr}^{3}, \mathrm{Thr}^{8}\right]$ octreotide ([$\left[{ }^{68} \mathrm{Ga}\right.$-DOTA $]$-TATE) was recently used in a patient with paraganglioma [32].

The main purpose of this work was to study the hypothesis that the influence of radiogallium on pharmacological parameters such as receptor binding affinity, rate of internalisation, tumour uptake etc. may be operative in new DOTA-octapeptides ("third-generation somatostatin analogues"). The latter differ from DOTA-TOC by virtue of an improved somatostatin receptor subtype profile [33, 34]. In PET these new radiopharmaceuticals may have the potential to target a wider range of tumours and to detect more lesions in an individual patient. Therefore we determined the affinity profiles with regard to hsst1-5 of ${ }^{68 / \text { nat }} \mathrm{Ga}$-DOTA-octapeptides and compared them with those of ${ }^{111 / \text { nat }}$ In-DOTA-octapeptides (or in some cases ${ }^{177 / n a t} \mathrm{Lu}$ and ${ }^{90 / \text { nat }}$ Y-DOTA-octapeptides). We also studied the rate of internalisation into sst2,3,5-expressing cell lines and the biodistribution in a rat tumour model (AR4-2J). In addition, we present first PET/CT studies using $\left[{ }^{68} \mathrm{Ga}\right.$-DOTA $]$-NOC in comparison to $\left[{ }^{68} \mathrm{Ga}\right.$-DOTA $]$-TATE.

\section{Materials and methods}

All chemicals, including Fmoc(9-fluorenylmethoxycarbonyl)-protected amino acids, were obtained from commercial sources and used without further purification. Tritylchloride-resin was obtained from PepChem (Tübingen, Germany). ${ }^{67} \mathrm{GaCl}_{3}$ and ${ }^{111} \mathrm{InCl}_{3}$ were from Mallinckrodt Medical (Petten, The Netherlands). The prochelator $\operatorname{DOTA}(\mathrm{tBu})_{3}$ was synthesised according to Heppeler et al. [20]. The reactive side chains of the amino acids were masked with one of the following groups: Cys, acetamidomethyl; Lys, $t$-butoxycarbonyl; Thr, $t$-butyl; Trp, $t$-butoxycarbonyl. Analytical reversed-phase high-performance liquid chromatography (RP-HPLC) was carried out on a Hewlett Packard 1050 HPLC system equipped with a multiwavelength detector and a flow-through Berthold LB506C1 $\gamma$-detector. Preparative HPLC was done on a Bischof HPLC-system (Metrohm AG, Switzerland) with HPLC-pumps 2250 and a Lambda 1010 UV-detector. CC250/4 Nucleosil 120-3C18 columns from MachereyNagel were used for analytical HPLC and a VP250/21 Nucleosil 200-5C15 column for preparative HPLC. The gradient systems consisted of mixtures of acetonitrile and water with $0.1 \%$ trifluoroacetic acid. Quantitative $\gamma$-counting was performed on a COBRA $5003 \gamma$-system well counter from Packard Instrument Company (Switzerland).

Electrospray ionisation-mass spectrometry (ESI-MS) was carried out with a Finnigan SSQ 7000 spectrometer (Bremen, Germany).

\section{Determination of lipophilicity}

The octanol-water partition coefficients were determined using the shake flask method. Both solvents (aqueous and octanol) were presaturated with each other by shaking them in contact for hours. To a solution of $100 \mathrm{nmol} / \mathrm{l}$ radiolabelled peptide in $500 \mu \mathrm{l}$ PBS (pH 7.4), $500 \mu \mathrm{l}$ of octanol was added $(n=5)$. The mixtures were vigorously shaken for $1 \mathrm{~h}$ to reach equilibrium. After equilibration, the mixtures 
were centrifuged (10 $\mathrm{min}$ at $2,000 \mathrm{rpm})$ to achieve good separation. The activity concentrations in $100-\mu 1$ samples of both the aqueous and the organic phase were measured in a $\gamma$-counter. The partition coefficient $(\log \mathrm{D})$ was calculated from the formula:

$\log \mathrm{D}=\log 10$

(counts in octanol layer/counts in aqueous layer)

\section{Synthesis}

The peptide-chelator conjugates were synthesised by standard Fmoc-solid phase synthesis [34] on tritylchloride resin (substitution $0.8 \mathrm{mmol} / \mathrm{g}$ ) on a Rink Engineering peptide synthesiser Switch 24 (RinkCombichem Technologies, Bubendorf, Switzerland) according to the general procedure described previously [33], affording compounds included in Fig. 1, which were characterised by ESI-MS and RP-HPLC.

Formation of metal complexes for preclinical studies

The DOTA-octapeptides were complexed with $\mathrm{InCl}_{3}$ (anhydrous), $\mathrm{Ga}\left(\mathrm{NO}_{3}\right)_{3} \cdot 5 \quad \mathrm{H}_{2} \mathrm{O} \quad \mathrm{Lu}\left(\mathrm{NO}_{3}\right)_{3} \cdot 9 \quad \mathrm{H}_{2} \mathrm{O}$ and $\mathrm{Y}$ $\left(\mathrm{NO}_{3}\right)_{3} \cdot 5 \mathrm{H}_{2} \mathrm{O}$ as described by Wild et al. [33]. The ligands were labelled with natural and radioactive indium or gallium $\left({ }^{111 / n a t}\right.$ In, ${ }^{67 / n a t} \mathrm{Ga}$ ) according to Ginj et al. [34] and obtained in $>99 \%$ radiochemical purity at specific activities of $>37 \mathrm{GBq} / \mu \mathrm{mol}$ peptide. For internalisation experiments, the DOTA-peptides were labelled to a specific activity of about $37 \mathrm{GBq} / \mu \mathrm{mol}$ peptide and then excess $\mathrm{InCl}_{3}$ (anhydrous) or $\mathrm{Ga}\left(\mathrm{NO}_{3}\right)_{3} \cdot 5 \mathrm{H}_{2} \mathrm{O}$ was added, followed

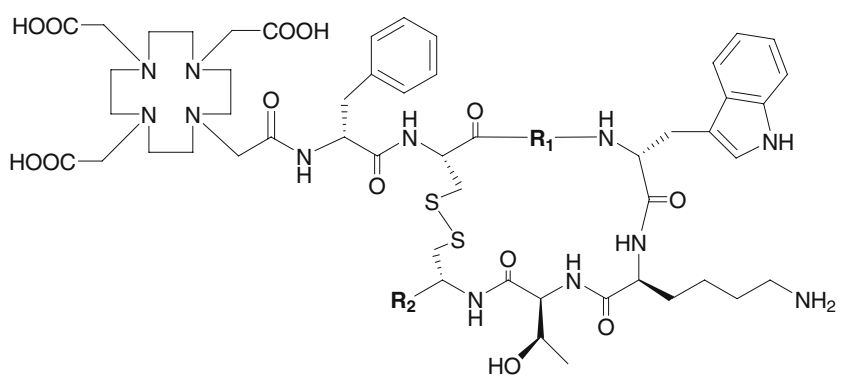

\begin{tabular}{lll}
\hline Compound & $\mathbf{R}_{\mathbf{1}}$ & $\mathbf{R}_{\mathbf{2}}$ \\
\hline DOTA-OC & $\mathrm{Phe}$ & $\mathrm{Thr}(\mathrm{ol})$ \\
DOTA-TOC & $\mathrm{Tyr}$ & $\mathrm{Thr}(\mathrm{ol})$ \\
DOTA-TATE & $\mathrm{Tyr}$ & $\mathrm{Thr}$ \\
DOTA-NOC & Nal-1 & $\mathrm{Thr}(\mathrm{ol})$ \\
DOTA-NOC-ATE & Nal-1 & $\mathrm{Thr}$ \\
DOTA-BOC & BzThi & $\mathrm{Thr}(\mathrm{ol})$ \\
DOTA-BOC-ATE & $\mathrm{BzThi}$ & $\mathrm{Thr}$ \\
\hline
\end{tabular}

Fig. 1 Structural formulae of the peptides studied by SepPak purification, to afford structurally characterised homogeneous peptide ligands.

Synthesis of $\left[{ }^{68} \mathrm{Ga}\right.$-DOTA]-NOC for clinical study

For the ${ }^{68} \mathrm{Ga}$ labelling, $30 \mathrm{mCi}{ }^{68} \mathrm{Ge} /{ }^{68} \mathrm{Ge}$ generators based on $\mathrm{TiO}_{2}$ phase (Cyclotron Co., Obninsk, Russia) were used to obtain $500-750 \mathrm{MBq}$ of ${ }^{68} \mathrm{Ga}$. The generator eluate was preconcentrated and purified from potential metallic impurities on a micro-chromatography cation exchange column (50W-X8, <400 mesh, Bio-Rad AG, Munich, Germany). The activities were eluted with $98 \%$ acetone $/ 0.05 \mathrm{~mol} /$ $1 \mathrm{HCl}(400 \mu \mathrm{l})$. This was added to $4 \mathrm{ml} \mathrm{H}_{2} \mathrm{O}$ containing $10 \mathrm{nmol}$ DOTA-NOC and heated at $100^{\circ} \mathrm{C}$ for $10 \mathrm{~min}$, leading to a radiochemical yield $>95 \%$. The mixture was subject to purification using Sep-Pak C18 cartridge, which was washed with $5 \mathrm{ml} \mathrm{H} \mathrm{H}_{2} \mathrm{O}$, followed by $0.5 \mathrm{ml}$ of ethanol diluted in $5 \mathrm{ml}$ of isotonic saline. After sterility filtration, quality control was performed using HPLC and thin-layer chromatography. [ $\left.{ }^{68} \mathrm{Ga}-\mathrm{DOTA}\right]-\mathrm{NOC}$ was obtained with specific activities of about $15 \mathrm{MBq} / \mu \mathrm{g}$ peptide.

Determination of somatostatin receptor affinity profiles

CHO-K1 and CCL39 cells stably expressing human sst1-5 (hsst1-5) were grown as described previously [35]. All culture reagents were supplied by GIBCO/BRL and Life Technologies (Grand Island, NY). Cell membrane pellets were prepared and receptor autoradiography was performed on pellet sections (mounted on microscope slides), as described in detail previously [35]. For each of the tested compounds, complete displacement experiments were performed with the universal somatostatin radioligand $\left[{ }^{125} \mathrm{I}\right]$-[Leu $\left.{ }^{8}, \mathrm{D}-\operatorname{Trp}^{22}, \operatorname{Trp}^{25}\right]$-somatostatin-28 using increasing concentrations of the Metallo ${ }^{\mathrm{III}}$-DOTA-peptide ranging from 0.1 to $1,000 \mathrm{nmol} / 1$. Somatostatin-28 was run in parallel as control using the same increasing concentrations. $\mathrm{IC}_{50}$ values were calculated after quantification of the data using a computer-assisted image processing system. Tissue standards (autoradiographic $\left[{ }^{125} \mathrm{I}\right]$ microscales, Amersham, UK) containing known amounts of isotopes, cross-calibrated to tissue-equivalent ligand concentrations, were used for quantification [35]. The concentrations of the peptide solutions were measured by UV spectroscopy $\left(\varepsilon_{\text {NOC-ATE, } 280 \mathrm{~nm}}=\right.$ $9,855 \mathrm{~cm}^{-1} \mathrm{~mol}^{-1} \mathrm{dm}^{3}, \varepsilon_{\text {BOC-ATE, } 280 \mathrm{~nm}}=7,570 \mathrm{~cm}^{-1} \mathrm{~mol}^{-1}$ $\mathrm{dm}^{3}, \varepsilon_{\text {TOC, }, 280 \mathrm{~nm}^{>}}=6,849 \mathrm{~cm}^{-1} \mathrm{~mol}^{-1} \mathrm{dm}^{3}, \varepsilon_{\mathrm{NOC}, 280 \mathrm{~nm}}>=$ $\left.9,850 \mathrm{~cm}^{-1} \mathrm{~mol}^{-1} \mathrm{dm}^{3}\right)$.

Cell culture, radioligand internalisation and cellular retention studies

The AR4-2J cell line was maintained by serial passage in mono-layers in Dulbecco's Modified Eagle's Medium 
(DMEM), supplemented with $10 \%$ fetal bovine serum, amino acids, vitamins and penicillin-streptomycin, in a humidified $5 \% \mathrm{CO}_{2}$ atmosphere at $37^{\circ} \mathrm{C}$. Human embryonic kidney (HEK) 293 cells stably expressing rat sst2, sst3 and sst5 receptors (a gift from Dr. S. Schulz, Magdeburg, Germany) [36] were grown in DMEM supplemented with $10 \%$ fetal bovine serum, penicillin-streptomycin and G418 $(500 \mu \mathrm{g} / \mathrm{ml})$ in a humidified $5 \% \mathrm{CO}_{2}$ atmosphere at $37^{\circ} \mathrm{C}$. Cell numbers were counted under the microscope with a Neubauer counting chamber. For all cell experiments, the cells were seeded at a density of $0.8-1.1$ million cells/well in six-well plates and incubated overnight with internalisation buffer to obtain a good cell adherence. The loss of cells during the internalisation experiments was below $10 \%$. When different radiolabelled peptides were compared in cell experiments, the same cell suspension-containing plates were used. Furthermore, the internalisation rate was linearly corrected to 1 million cells/well.

Medium was removed from the six-well plates and cells were washed once with $2 \mathrm{ml}$ of internalisation buffer (DMEM, 1\% fetal bovine serum, amino acids and vitamins, $\mathrm{pH}$ 7.4). Furthermore, $1.5 \mathrm{ml}$ internalisation buffer was added to each well and incubated at $37^{\circ} \mathrm{C}$ for about $1 \mathrm{~h}$. Thereafter approximately $500,000 \mathrm{cpm}$ or $0.02 \mathrm{MBq} / \mathrm{well}$ ${ }^{67} \mathrm{Ga} / \mathrm{Ga}^{\mathrm{III}}$ - and ${ }^{111} \mathrm{In} / \mathrm{In}^{\mathrm{III}}$-labelled peptides $(2.5 \mathrm{pmol} / \mathrm{well})$ to a final concentration of $1.67 \mathrm{nmol} / 1$ were added to the medium and the cells were incubated in triplicate at $37^{\circ} \mathrm{C}$ for the indicated time periods. To determine non-specific membrane binding and internalisation, cells were incubated with the radioligand in the presence of $1 \mu \mathrm{mol} / 1\left[\mathrm{In}^{\mathrm{III}}\right.$ DOTA]-NOC. Cellular uptake was stopped by removing the medium from the cells and by washing twice with $1 \mathrm{ml}$ ice-cold PBS. An acid wash for 10 min with a glycine buffer $\mathrm{pH} 2.8$ on ice was also performed twice. This procedure was performed to distinguish between membrane-bound (acid-releasable) and internalised (acid-resistant) radioligand. Finally, the cells were treated with $1 \mathrm{~mol} / \mathrm{l}$ $\mathrm{NaOH}$. The culture medium, the receptor-bound and the internalised fraction were measured radiometrically in a $\gamma$ counter (Packard, Cobra II).

For cellular retention studies, HEK-sst2 cells (1 million) were incubated with $2.5 \mathrm{pmol} /$ well $(1.67 \mathrm{nmol} / \mathrm{l})\left[{ }^{111} \mathrm{In} /\right.$ $\left.\mathrm{In}^{\mathrm{III}}\right]$ - or $\left[{ }^{67} \mathrm{Ga} / \mathrm{Ga}^{\mathrm{III}}\right]$-labelled DOTA-NOC, DOTA-BOC or DOTA-TOC for $120 \mathrm{~min}$, respectively, then the medium was removed and the wells were washed twice with $1 \mathrm{ml}$ ice-cold PBS. In each experiment an acid wash for $10 \mathrm{~min}$ on ice with a glycine buffer of $\mathrm{pH} 2.8$ was performed twice to remove the receptor-bound ligand. Cells were then incubated again at $37^{\circ} \mathrm{C}$ with fresh internalisation buffer (DMEM containing 1\% fetal bovine serum, $\mathrm{pH}$ 7.4). After different time points the external medium was removed for quantification of radioactivity in a $\gamma$-counter and replaced with fresh $37^{\circ} \mathrm{C}$ medium. The cells were solubilised in
$1 \mathrm{~mol} / \mathrm{l} \mathrm{NaOH}$ and removed, and the internalised radioactivity was quantified in a $\gamma$-counter. The externalised fraction was expressed as percentage of the total internalised amount per 1 million cells.

\section{Biodistribution studies in tumour-bearing rats}

Animals were kept, treated and cared for in compliance with the guidelines of the Swiss regulations (approval \#789). Five-week-old male Lewis rats were implanted subcutaneously with 10-12 million AR4-2J cells freshly suspended in sterile PBS. Fourteen days after inoculation, the rats showed solid palpable tumour masses (tumour weight $0.4-0.7 \mathrm{~g}$ ) and were used for the experiments. Rats were injected under ether anaesthesia with $2-3 \mathrm{MBq}$ of $0.34 \mathrm{nmol}(0.5 \mu \mathrm{g}$ total peptide mass) [ ${ }^{111} \mathrm{In}$-DOTA $]$-NOC, $\left[{ }^{67} \mathrm{Ga}-\mathrm{DOTA}\right]-\mathrm{NOC}$ or $\left[{ }^{67} \mathrm{Ga}-\mathrm{DOTA}\right]-\mathrm{TOC}$, in $0.05 \mathrm{ml} \mathrm{NaCl}$ solution $0.9 \%$ into the femoral vein. At $4 \mathrm{~h}$ and $24 \mathrm{~h}$ after injection rats were sacrificed under ether anaesthesia. Organs and blood were collected and the radioactivity in these samples was determined using a $\gamma$-counter.

In order to determine the non-specific uptake of the radiopeptides, rats were injected with $50 \mu \mathrm{g}$ [ $\mathrm{In}^{\mathrm{III}}$-DOTA]NOC in $0.05 \mathrm{ml} \mathrm{NaCl}$ solution $0.9 \%$ as a co-injection with the radioligand.

\section{Patient study}

Whole-body PET/CT scan was performed on a Siemens biograph duo (Siemens, Germany). The 65-year-old male patient was operated on owing to a neuroendocrine pancreatic carcinoma (immunohistochemical staining positive for chromogranin and CD56) 6 months before the PET/CT study by left pancreatectomy, splenectomy and resection of a single liver metastasis in the left lobe (segment SII). Postoperative treatment with octreotide (Sandostatin LAR $20 \mathrm{mg} /$ month) was started and stopped 4 weeks before the first PET/CT study.

Statistical methods

To compare differences between the radiopeptides, Student's $t$ test was used. $P$ values $<0.05$ were considered significant.

\section{Results}

The peptides conjugated to DOTA presented in Fig. 1 were synthesised by solid phase synthesis [33, 35]. Their complexes were characterised by analytical HPLC and ESI-MS. Radioligands were obtained at specific activities of $>37 \mathrm{GBq} / \mu \mathrm{mol}$ and a radiochemical purity of $>97 \%$. 
Receptor binding and affinity profiles

Table 1 summarises the $\mathrm{IC}_{50}$ values of the radiopeptides as their $\mathrm{In}^{\mathrm{III}}$ - and $\mathrm{Ga}^{\mathrm{III}}$-complexed versions for the human somatostatin receptors $1-5$ (hsst1-hsst5), including data published previously [35]. As a reference peptide, natural somatostatin-28 is included. The values were obtained by performing complete competition experiments with the universal radioligand $\left[{ }^{125} \mathrm{I}\right]\left[\mathrm{Leu}^{8}, \mathrm{D}-\mathrm{Trp}^{22}{ }^{2} \mathrm{Tyr}^{25}\right]$ somatostatin-28. In some cases the values for the $\mathrm{Lu}^{\mathrm{III}}$ - and/or $\mathrm{Y}^{\mathrm{III}}$-complexed peptides were included along with the $\mathrm{Ga}^{\mathrm{III}}$-peptides because all $\mathrm{IC}_{50}$ values, including those for somatostatin-28, were determined in the same assay.

All metallopeptides bind with high affinity to hsst2 in the low nanomolar range, with a significantly higher binding affinity of the $\mathrm{Ga}^{\mathrm{III}}$-complexed DOTA-peptides compared to the other metallopeptides ( $\mathrm{In}^{\mathrm{III}}{ }_{-}, \mathrm{Lu}^{\mathrm{III}}-$, $\mathrm{Y}^{\mathrm{III}}$ complexed versions): differences range between two- and eight-fold, depending on the assay. This holds for the peptides included in Fig. 1 [octreotide, $\left[\mathrm{Tyr}^{3}\right.$ ] octreotide (TOC), $\left[1-\mathrm{Nal}^{3}, \mathrm{Thr}^{8}\right]$ octreotide (NOC-ATE), [Tyr $\left.{ }^{3}, \mathrm{Thr}^{8}\right]$ octreotide (TATE), $\left[1-\mathrm{Nal}^{3}\right]$ octreotide (NOC) and $\left[\mathrm{BzTh}^{3}\right]$ octreotide (BOC)]. On hsst3 the $\mathrm{IC}_{50}$ values for the $\mathrm{Ga}^{\mathrm{III}}$ DOTA-octapeptides were higher (affinity was lower) than on hsst2. In addition and conversely to the hsst 2 situation, the binding affinity of $\mathrm{Ga}^{\mathrm{III}}$-complexed peptides was lower than that of the other metallopeptides. On hsst4 the affinity is very low for most of the peptides, with a few exceptions.
Again, a tendency is seen for the $\mathrm{Ga}^{\mathrm{III}}$-peptides to have a somewhat higher affinity. On hsst5 all new metallopeptides show good affinity, again with a tendency towards higher affinity of the $\mathrm{Ga}^{\mathrm{III}}$-complexed peptides with the exception of $\left[\mathrm{Ga}^{\mathrm{III}}\right.$-DOTA]-NOC-ATE.

Internalisation studies in AR4-2J, HEK-sst2 and HEK-sst3 cells

Figure 2 shows a typical example of the time-dependent internalisation of [ $\left[{ }^{68} \mathrm{Ga}-\mathrm{DOTA}\right]-\mathrm{NOC}$ and [ [ ${ }^{111} \mathrm{In}$-DOTA]NOC into the AR4-2J cell line. Table 2 summarises the internalised percentage of several other octapeptides coupled to DOTA and labelled with ${ }^{67} \mathrm{Ga}$ and ${ }^{111} \mathrm{In}$ at $4 \mathrm{~h}$ in the three cell lines HEK-sst2, HEK-sst3 and AR4-2J. After $4 \mathrm{~h}$, $23.9 \% \pm 1.5 \%\left(2.5 \mathrm{pmol} / 10^{6}\right.$ cells $)$ of $\left[{ }^{111} \mathrm{In}-\mathrm{DOTA}\right]-\mathrm{NOC}$ was internalised into AR4-2J cells, while the corresponding value for $\left[{ }^{67} \mathrm{Ga}-\mathrm{DOTA}\right]-\mathrm{NOC}$ was $41.1 \% \pm 0.6 \%$. In HEKsst 2 cells the respective values were $25 \% \pm 1.5 \%$ and $50 \% \pm$ $2 \%$. Corresponding values for $\left[{ }^{111}\right.$ In-DOTA $]-T O C$ and $\left[{ }^{67} \mathrm{Ga}-\mathrm{DOTA}\right]-\mathrm{TOC}$ in AR4-2J cells were $11.5 \% \pm 0.7 \%$ and $16.5 \% \pm 1.0 \%$, respectively, whereas in the HEK-sst2 cells they were $16 \% \pm 0.5 \%$ and $35 \% \pm 1.0 \%$, respectively. The specific uptake in HEK-sst3 cells was lower for all radiopeptides. For this receptor the ${ }^{111}$ In-labelled peptides internalised significantly better than the ${ }^{67} \mathrm{Ga}$-labelled ones, with the exception of $\left[{ }^{111} \mathrm{In}\right.$-DOTA $]-\mathrm{NOC} /\left[{ }^{67} \mathrm{Ga}\right.$-DOTA $]$ NOC, which internalised at an equal rate. No internalisation

Table 1 Affinity profiles of DOTA-octapeptides $\left(\mathrm{IC}_{50}\right)$ for hsst1-5 receptors

\begin{tabular}{|c|c|c|c|c|c|}
\hline Compound & hsst1 & hsst2 & hsst3 & hsst4 & hsst5 \\
\hline Somatostatin-28 & $3.8 \pm 0.3(10)$ & $2.5 \pm 0.3(11)$ & $5.7 \pm 0.6(10)$ & $4.2 \pm 0.3(11)$ & $3.7 \pm 0.4(11)$ \\
\hline Ga-DOTA-NOC & $>10,000(3)$ & $1.9 \pm 0.4(3)$ & $40.0 \pm 5.8$ & $260 \pm 74(3)$ & $7.2 \pm 1.6(3)$ \\
\hline In-DOTA-NOC & $>10,000$ & $2.9 \pm 0.1(3)^{b}$ & $8.0 \pm 2.0(3)^{\mathrm{b}}$ & $227 \pm 18$ & $11.2 \pm 3.5(3)$ \\
\hline Lu-DOTA-NOC & $>10,000$ & $3.4 \pm 0.4(3)^{\mathrm{b}}$ & $12.0 \pm 3.3(3)^{b}$ & $747 \pm 47(3)^{\mathrm{b}}$ & $14.0 \pm 3.5(3)^{b}$ \\
\hline In-DOTA-BOC & $>1,000(2)$ & $4.4 \pm 0.4(3)^{b}$ & $6.8 \pm 0.3(3)^{b}$ & ND & $10.5 \pm 1.5(3)^{b}$ \\
\hline Lu-DOTA-BOC & $>1,000(2)$ & $4.0 \pm 0.4(3)^{\mathrm{b}}$ & $6.3 \pm 0.2(3)^{b}$ & $591 \pm 88(2)$ & $6.5 \pm 0.1(3)^{b}$ \\
\hline Ga-DOTA-BOC & $700 \pm 300(2)$ & $1.7 \pm 0.2(3)$ & $10.5 \pm 0.5(3)$ & ND & $4.4 \pm 1.2(3)$ \\
\hline Y-DOTA-NOC-ATE & $>1,000(2)$ & $4.2 \pm 2.0$ & $47 \pm 1$ & ND & $12 \pm 1(3)^{b}$ \\
\hline Lu-DOTA-NOC-ATE & $>1,000(2)$ & $3.6 \pm 0.3(3)^{\mathrm{b}}$ & $30 \pm 2(3)$ & ND & $15 \pm 1(3)^{b}$ \\
\hline Ga-DOTA-NOC-ATE & $>1,000(2)$ & $2.6 \pm 0.3(3)$ & $113 \pm 80(2)$ & $53 \pm 30(2)$ & $25 \pm 4(3)$ \\
\hline Y-DOTA-BOC-ATE & $>1,000(2)$ & $2.9 \pm 0.3(3)^{b}$ & $23 \pm 1$ & ND & $7.8 \pm 2.0$ \\
\hline Ga-DOTA-BOC-ATE & $>1,000(2)$ & $2.0 \pm 0.2$ & $33 \pm 23(2)$ & $35 \pm 24(2)$ & $19.5 \pm 13.0$ \\
\hline Somatostatin- $28^{\mathrm{a}}$ & $5.2 \pm 0.3(19)$ & $2.7 \pm 0.3(19)$ & $7.7 \pm 0.9(15)$ & $5.6 \pm 0.4(19)$ & $4.0 \pm 0.3(19)$ \\
\hline Ga-DOTA-TOC ${ }^{\mathrm{a}}$ & $>10,000$ & $2.5 \pm 0.5$ & $613 \pm 140$ & $>1,000$ & $73 \pm 21$ \\
\hline Y-DOTA-TOC & $>10,000$ & $11.0 \pm 1.7^{\mathrm{b}}$ & $389 \pm 135$ & $>10,000$ & $114 \pm 29$ \\
\hline Ga-DOTA-OC ${ }^{\mathrm{a}}$ & $>10,000$ & $7.3 \pm 1.9$ & $120 \pm 45$ & $>1,000$ & $60 \pm 14$ \\
\hline Y-DOTA-OC & $>10,000$ & $20 \pm 2^{b}$ & $27 \pm 8^{b}$ & $>10,000$ & $57 \pm 22$ \\
\hline Ga-DOTA-TATE & $>10,000$ & $0.20 \pm 0.04$ & $>1,000$ & $300 \pm 140$ & $377 \pm 18$ \\
\hline Y-DOTA-TATE & $>10,000$ & $1.6 \pm 0.4^{\mathrm{b}}$ & $>1,000$ & $523 \pm 239$ & $187 \pm 50^{\mathrm{b}}$ \\
\hline
\end{tabular}

$\mathrm{IC}_{50}$ values are in nmol/1 (mean $\left.\pm \mathrm{SEM}\right)$. Number of independent studies is given in parentheses. Somatostatin-28 was used as control ND not determined

${ }^{\text {a }}$ Data including the control peptide somatostatin-28 are from Reubi et al. [35]

${ }^{\mathrm{b}}$ Significant difference $(p<0.05)$ of the $\mathrm{Ga}^{\mathrm{III}}$-complexed peptides vs the other metallopeptides 


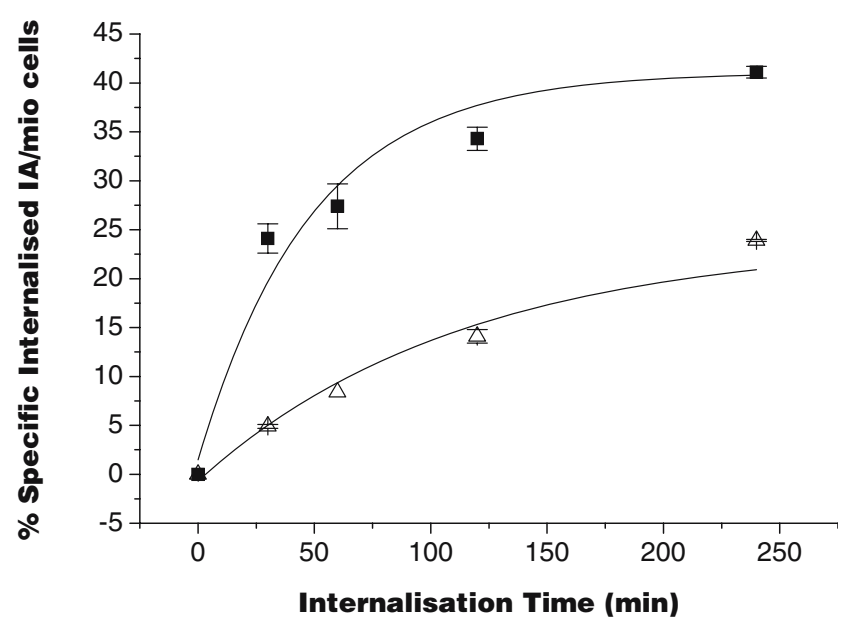

Fig. 2 Comparison of the rate of internalisation of [ ${ }^{111}$ In-DOTA]NOC $(\Delta)$ and $\left[{ }^{67}\right.$ Ga-DOTA]-NOC ( $)$ into AR4-2J cells. Values and standard deviations are the result of three independent experiments with triplicates in each experiment and are expressed as specific internalisation (percentage of activity added to 1 million cells at $1.67 \mathrm{nmol} / 1$ concentration, $37^{\circ} \mathrm{C}$ )

was found for $\left[{ }^{111}\right.$ In-DOTA $]-T O C$ or $\left[{ }^{67}\right.$ Ga-DOTA $]-T O C$ in HEK-sst 3 cells.

Efflux was studied with HEK-sst2 cells, which were allowed to internalise the radioligands for $2 \mathrm{~h}$. The percentage of externalised radiopeptide at $4 \mathrm{~h}$ was $30 \pm$ $2 \%$ for $\left[{ }^{67} \mathrm{Ga}\right.$-DOTA $]-\mathrm{NOC}, 30 \pm 5 \%$ for $\left[{ }^{67} \mathrm{Ga}-\mathrm{DOTA}\right]-$ TOC, $25 \pm 3 \%$ for [ $\left.{ }^{111} \mathrm{In}-\mathrm{DOTA}\right]-\mathrm{NOC}$ and $25 \pm 4 \%$ for $\left[{ }^{111} \mathrm{In}-\mathrm{DOTA}\right]-\mathrm{BOC}$.

\section{Biodistribution in AR4-2J tumour-bearing rats}

The 4-h and 24-h uptake values of $\left[{ }^{67}\right.$ Ga-DOTA]-NOC and $\left[{ }^{111}\right.$ In-DOTA $]-N O C$ in Lewis rats bearing the AR4-2J rat pancreatic tumour in sst-positive organs such as the pancreas, adrenals, pituitary and stomach, in the tumour and in other tissues are shown in Table 3, in comparison with the values for $\left[{ }^{67} \mathrm{Ga}\right.$-DOTA $]$-TOC. The three radiopeptides showed rapid blood clearance with very low levels of radioactivity remaining in blood at $4 \mathrm{~h}: 0.02 \% \pm 0.00 \%$ $\mathrm{IA} / \mathrm{g}$ for $\left[{ }^{111} \mathrm{In}\right.$-DOTA]-NOC $(\% \mathrm{IA} / \mathrm{g}$ is the percentage of injected activity per gram tissue), $0.03 \% \pm 0.01 \% \mathrm{IA} / \mathrm{g}$ for $\left[{ }^{67} \mathrm{Ga}-\mathrm{DOTA}\right]-\mathrm{NOC}$ and $0.07 \% \pm 0.006 \% \mathrm{IA} / \mathrm{g}$ for $\left[{ }^{67} \mathrm{Ga}-\right.$ DOTA]-TOC. At $24 \mathrm{~h}$ the blood activity was down to $0.01 \% \mathrm{IA} / \mathrm{g}$ for all three radiopeptides. The uptake in the tumour was high at $4 \mathrm{~h}$ and receptor mediated, as shown by a separate blocking experiment: co-injection of $100 \mu \mathrm{g}$ DOTA-NOC resulted in $>92 \%$ blockage of tumour uptake. $\left[{ }^{67} \mathrm{Ga}-\mathrm{DOTA}\right]-\mathrm{NOC}$ accumulated specifically and significantly higher in the tumour than did $\left[{ }^{111}\right.$ In-DOTA $]-N O C$ at $4 \mathrm{~h}$ and $24 \mathrm{~h}$. Higher uptake of $\left[{ }^{67} \mathrm{Ga}\right.$-DOTA $]-\mathrm{NOC}$ was also found in most other somatostatin receptor-positive organs such as the adrenals, the bowel and the pituitary. The specificity of uptake in these organs was again demonstrated by blocking of the organs with excess cold peptide. Co-injection of $100 \mu \mathrm{g}$ DOTA-NOC efficiently blocked (by $>93 \%$ ) the uptake in all of these organs except the bowel, where the blocking was by $81 \%$. No blocking was found for the liver, the kidneys or the spleen.

The liver uptake of $\left[{ }^{67} \mathrm{Ga}-\mathrm{DOTA}\right]-\mathrm{NOC}$ was relatively high $(0.95 \% \pm 0.09 \% \mathrm{IA} / \mathrm{g}$ at $4 \mathrm{~h})$ and significantly higher than that of $\left[{ }^{111}\right.$ In-DOTA]-NOC $(0.21 \% \pm 0.04 \%$ IA $/ \mathrm{g})$. The lowest liver uptake at $4 \mathrm{~h}$ was found for $\left[{ }^{67} \mathrm{Ga}-\mathrm{DOTA}\right]-$ TOC $(0.09 \% \pm 0.01 \% \mathrm{IA} / \mathrm{g})$. The kidney uptake was lowest for $\left[{ }^{67} \mathrm{Ga}\right.$-DOTA $]-\mathrm{NOC}(0.95 \% \pm 0.18 \%$ IA $/ \mathrm{g}$ at $4 \mathrm{~h}$; $0.79 \% \pm 0.06 \% \mathrm{IA} / \mathrm{g}$ at $24 \mathrm{~h}$ ), followed by [ $\left.{ }^{111} \mathrm{In}-\mathrm{DOTA}\right]-$ NOC $(1.37 \% \pm 0.21 \% \mathrm{IA} / \mathrm{g}$ at $4 \mathrm{~h}, 1.27 \% \pm 0.1 \% \mathrm{IA} / \mathrm{g}$ at

Table 2 Internalisation of $\left[{ }^{67} \mathrm{Ga}\right]$ - or $\left[{ }^{111} \mathrm{In}\right]$-labelled peptides into AR4-2J, HEK-sst2 and HEK-sst3 cells after 4-h incubation at $37^{\circ} \mathrm{C}^{\mathrm{a}}$

\begin{tabular}{|c|c|c|c|}
\hline Radiopeptide & $\begin{array}{l}\% \text { internalised in } \\
\text { AR4- } 2 \mathrm{~J} \text { cells }\end{array}$ & $\begin{array}{l}\% \text { internalised in } \\
\text { HEK-sst } 2 \text { cells }\end{array}$ & $\begin{array}{l}\% \text { internalised in } \\
\text { HEK-sst } 3 \text { cells }\end{array}$ \\
\hline$\left[{ }^{67} \mathrm{Ga}-\mathrm{DOTA}\right]-\mathrm{TOC}$ & $16.50 \pm 1.0$ & $35.0 \pm 1.0$ & $<0.1$ \\
\hline$\left[{ }^{111}\right.$ In-DOTA]-TOC & $11.50 \pm 0.7$ & $16.0 \pm 0.5$ & $<0.1$ \\
\hline$\left[{ }^{67} \mathrm{Ga}-\mathrm{DOTA}\right]$-TATE & $33.7 \pm 1.3$ & $45.4 \pm 0.7$ & $<0.6$ \\
\hline$\left[{ }^{111}\right.$ In-DOTA]-TATE & $21.0 \pm 2.3^{\mathrm{b}}$ & ND & ND \\
\hline$\left[{ }^{67} \mathrm{Ga}-\mathrm{DOTA}\right]-\mathrm{NOC}$ & $41.1 \pm 0.6$ & $50.0 \pm 2.0$ & $14.3 \pm 0.5$ \\
\hline$\left[{ }^{111}\right.$ In-DOTA]-NOC & $23.9 \pm 1.5$ & $25.0 \pm 1.5$ & $14.0 \pm 1.0$ \\
\hline$\left[{ }^{67} \mathrm{Ga}-\mathrm{DOTA}\right]-\mathrm{NOC}-\mathrm{ATE}$ & $28.3 \pm 1.6$ & $50.0 \pm 3.0$ & $2.4 \pm 0.15$ \\
\hline$\left[{ }^{111}\right.$ In-DOTA]-NOC-ATE & $25.1 \pm 1.3$ & $29.0 \pm 2.0$ & $13.6 \pm 0.8$ \\
\hline$\left[{ }^{67} \mathrm{Ga}-\mathrm{DOTA}\right]-\mathrm{BOC}$ & $26.5 \pm 1.3$ & $55.9 \pm 1.2$ & $18.5 \pm 1.1$ \\
\hline$\left[{ }^{111}\right.$ In-DOTA]-BOC & $17.2 \pm 1.9$ & $38.7 \pm 0.9$ & $24.3 \pm 0.9$ \\
\hline$\left[{ }^{67} \mathrm{Ga}-\mathrm{DOTA}\right]-\mathrm{BOC}-\mathrm{ATE}$ & $23.7 \pm 0.6$ & $56.0 \pm 0.5$ & $4.1 \pm 0.5$ \\
\hline$\left[{ }^{111}\right.$ In-DOTA]-BOC-ATE & $17.8 \pm 0.8$ & $51.1 \pm 0.95$ & $20.1 \pm 0.5$ \\
\hline
\end{tabular}

$N D$ not determined

${ }^{a}$ Specific internalisation (\% activity added to 1 million cells at $1.67 \mathrm{nmol} / 1$ concentration) and result of three independent experiments with triplicates in each experiment; Student's $t$ test yielded significant differences $(p$ values $<0.02)$ for the comparison of all $\left[{ }^{67}\right.$ Ga-DOTA]- vs $\left[{ }^{111}\right.$ InDOTA]-peptides on sst2 (AR4-2J and HEK-sst2) and HEK-sst3 with the exception of $\left[{ }^{67}\right.$ Ga-DOTA]-NOC vs [ ${ }^{111}$ In-DOTA]-NOC in HEK-sst3 ${ }^{\mathrm{b}}$ From ref. [4]. 
Table 3 Biodistribution in AR4-2J tumour-bearing rats and tissue ratios at $4 \mathrm{~h}$ and $24 \mathrm{~h}$ p.i. of $\left[{ }^{111} \mathrm{In}-\mathrm{DOTA}\right]-\mathrm{NOC}$, [ $\left.{ }^{67} \mathrm{Ga}-\mathrm{DOTA}\right]-\mathrm{NOC}$ and $\left[{ }^{67} \mathrm{Ga}-\mathrm{DOTA}\right]-\mathrm{TOC}$

\begin{tabular}{|c|c|c|c|c|c|c|c|c|c|}
\hline \multirow[t]{2}{*}{ Site } & \multicolumn{3}{|c|}{$\left[{ }^{111} \mathrm{In}-\mathrm{DOTA}\right]-\mathrm{NOC}$} & \multicolumn{3}{|c|}{$\left[{ }^{67} \mathrm{Ga}-\mathrm{DOTA}\right]-\mathrm{NOC}$} & \multicolumn{3}{|c|}{$\left[{ }^{67} \mathrm{Ga}-\mathrm{DOTA}\right]-\mathrm{TOC}$} \\
\hline & $4 \mathrm{~h}$ & 4 h blocked $^{\mathrm{a}}$ & $24 \mathrm{~h}$ & $4 \mathrm{~h}$ & $4 \mathrm{~h}$ blocked $^{\mathrm{a}}$ & $24 \mathrm{~h}$ & $4 \mathrm{~h}$ & 4 h blocked $^{\mathrm{a}}$ & $24 \mathrm{~h}$ \\
\hline Blood & $0.02 \pm 0.00$ & $0.03 \pm 0.01$ & $0.01 \pm 0.00$ & $0.03 \pm 0.01$ & $0.02 \pm 0.01$ & $0.01 \pm 0.00$ & $0.07 \pm 0.006^{* *}$ & $0.06 \pm 0.00$ & $0.01 \pm 0.005$ \\
\hline Tumour & $2.96 \pm 0.48$ & $0.24 \pm 0.01$ & $2.65 \pm 0.41$ & $4.24 \pm 0.37 *$ & $0.30 \pm 0.00$ & $4.02 \pm 0.32 *$ & $4.6 \pm 1.18^{* *}$ & $0.28 \pm 0.00$ & $2.70 \pm 0.17 * *$ \\
\hline Kidneys & $1.37 \pm 0.21$ & $1.83 \pm 0.02$ & $1.27 \pm 0.10$ & $0.95 \pm 0.18$ & $0.91 \pm 0.13$ & $0.79 \pm 0.06^{*}$ & $1.55 \pm 0.25 * *$ & $1.64 \pm 0.018$ & $1.37 \pm 0.18^{* *}$ \\
\hline Adrenals & $8.24 \pm 1.16$ & $0.55 \pm 0.07$ & $1.02 \pm 0.17$ & $14.14 \pm 1.46^{*}$ & $0.32 \pm 0.05$ & $6.46 \pm 0.60 *$ & $10.90 \pm 0.35^{* *}$ & $0.16 \pm 0.00$ & $6.35 \pm 0.64$ \\
\hline Pancreas & $7.94 \pm 0.71$ & $0.16 \pm 0.03$ & $4.04 \pm 0.29$ & $7.13 \pm 0.63$ & $0.34 \pm 0.04$ & $3.15 \pm 0.62$ & $13.32 \pm 0.78^{* *}$ & $0.299 \pm 0.00$ & $6.14 \pm 1.04^{* *}$ \\
\hline Spleen & $0.09 \pm 0.01$ & $0.09 \pm 0.03$ & $0.09 \pm 0.02$ & $0.12 \pm 0.02$ & $0.13 \pm 0.03$ & $0.13 \pm 0.04$ & $0.08 \pm 0.01 * *$ & $0.088 \pm 0.00$ & $0.14 \pm 0.11$ \\
\hline Stomach & $1.64 \pm 0.19$ & $0.05 \pm 0.02$ & $1.08 \pm 0.11$ & $1.99 \pm 0.23$ & $0.07 \pm 0.01$ & $0.91 \pm 0.05$ & $1.76 \pm 0.11$ & $0.06 \pm 0.00$ & $0.912 \pm 0.22$ \\
\hline Bowel & $0.36 \pm 0.26$ & $0.07 \pm 0.01$ & $0.27 \pm 0.15$ & $0.26 \pm 0.04$ & $0.04 \pm 0.01$ & $0.79 \pm 0.06^{*}$ & $0.23 \pm 0.02$ & $0.04 \pm 0.00$ & $0.18 \pm 0.006^{* *}$ \\
\hline Liver & $0.21 \pm 0.04$ & $0.22 \pm 0.02$ & $0.15 \pm 0.01$ & $0.95 \pm 0.09^{*}$ & $1.04 \pm 0.11$ & $0.93 \pm 0.05^{*}$ & $0.09 \pm 0.01 * *$ & $0.12 \pm 0.00$ & $0.10 \pm 0.07 * *$ \\
\hline Lung & $0.06 \pm 0.01$ & $0.05 \pm 0.001$ & $0.05 \pm 0.02$ & $0.13 \pm 0.02 *$ & $0.12 \pm 0.01$ & $0.13 \pm 0.03 *$ & $0.09 \pm 0.01 * *$ & $0.08 \pm 0.00$ & $0.11 \pm 0.10$ \\
\hline Heart & $0.01 \pm 0.00$ & $0.02 \pm 0.004$ & $0.01 \pm 0.00$ & $0.05 \pm 0.00$ & $0.04 \pm 0.01$ & $0.04 \pm 0.01 *$ & $0.03 \pm 0.01 * *$ & $0.02 \pm 0.00$ & $0.015 \pm 0.003^{* *}$ \\
\hline Pituitary & $6.21 \pm 0.73$ & $0.18 \pm 0.05$ & $5.44 \pm 0.79$ & $11.08 \pm 1.41^{*}$ & $0.20 \pm 0.03$ & $6.00 \pm 0.66$ & $10.33 \pm 1.90$ & $0.21 \pm 0.00$ & $6.65 \pm 0.06$ \\
\hline \multicolumn{10}{|c|}{ Tumour to tissue ratios } \\
\hline Tumour/blood & 148.0 & & 265.0 & 142.0 & & 402.0 & 68.5 & & 270.0 \\
\hline Tumour/kidney & 2.2 & & 2.1 & 4.5 & & 5.1 & 3.1 & & 1.97 \\
\hline Tumour/liver & 14.1 & & 17.7 & 4.5 & & 4.3 & 53.2 & & 27.0 \\
\hline
\end{tabular}

Values are the mean of $\% \mathrm{IA} / \mathrm{g} \pm \mathrm{SD}$ for groups of three or four animals $I A$ injected activity

*** Significant differences $(p<0.05)$ : *between $\left[{ }^{111}\right.$ In-DOTA $]$-NOC and $\left[{ }^{67}\right.$ Ga-DOTA $]-N O C ; * *$ between $\left[{ }^{67}\right.$ Ga-DOTA $]-N O C$ and $\left[{ }^{67} \mathrm{Ga}-\mathrm{DOTA}\right]-\mathrm{TOC}$

${ }^{\text {a }}$ Blocked with $0.1 \mathrm{mg}$ DOTA-NOC as a co-injection with the radiopeptide

$24 \mathrm{~h})$ and $\left[{ }^{67} \mathrm{Ga}-\mathrm{DOTA}\right]-\mathrm{TOC}(1.55 \% \pm 0.25 \% \mathrm{IA} / \mathrm{g}$ at $4 \mathrm{~h}$; $1.37 \% \pm 0.18 \% \mathrm{IA} / \mathrm{g}$ at $24 \mathrm{~h})$.

Owing to the fast blood clearance, the tumour-to-blood ratio was very high for all three radiopeptides. At $4 \mathrm{~h}$ it was 142 for $\left[{ }^{67} \mathrm{Ga}\right.$-DOTA]-NOC, 148 for $\left[{ }^{111} \mathrm{In}\right.$-DOTA $]$-NOC and 68 for $\left[{ }^{67} \mathrm{Ga}\right.$-DOTA $]$-TOC. The ratios increased to 402 , 265 and 270 , respectively, at $24 \mathrm{~h}$. The tumour-to-kidney ratio at $4 \mathrm{~h}$ was 4.5 for $\left[{ }^{67} \mathrm{Ga}-\mathrm{DOTA}\right]-\mathrm{NOC}, 2.2$ for $\left[{ }^{111} \mathrm{In}\right.$ DOTA $]$-NOC and 3.1 for $\left[{ }^{67} \mathrm{Ga}-\mathrm{DOTA}\right]-\mathrm{TOC}$. The ratio increased somewhat for $\left[{ }^{67} \mathrm{Ga}-\mathrm{DOTA}\right]-\mathrm{NOC}$ at $24 \mathrm{~h}$ (to 5.1) but decreased for the two other peptides. Whereas the tumour-to-liver ratio was very high for $\left[{ }^{67} \mathrm{Ga}\right.$-DOTA $]$-TOC (53.2 at $4 \mathrm{~h}$ and 27 at $24 \mathrm{~h}$ ), it was 14.1 at $4 \mathrm{~h}$ and 17.7 at $24 \mathrm{~h}$, respectively, for [ $\left.{ }^{111} \mathrm{In}-\mathrm{DOTA}\right]-\mathrm{NOC}$ and 4.5 at $4 \mathrm{~h}$ and 4.3 at $24 \mathrm{~h}$ for $\left[{ }^{67} \mathrm{Ga}\right.$-DOTA $]-\mathrm{NOC}$.

A clinical case report comparing $\left[{ }^{68}\right.$ Ga-DOTA $]$-NOC with $\left[{ }^{68} \mathrm{Ga}\right.$-DOTA $]$-TATE

In Fig. 3 an example is given of a patient with a neuroendocrine pancreatic carcinoma. The patient was scanned with $\left[{ }^{68} \mathrm{Ga}-\mathrm{DOTA}\right]-\mathrm{NOC}$ (Fig. 3a), $\left[{ }^{68} \mathrm{Ga}-\right.$ DOTA]-TATE (Fig. 3b) and $\left[{ }^{18} \mathrm{~F}\right]$ fluorodeoxyglucose (FDG) (Fig. 3d). Eighty-five $\mathrm{MBq}\left[{ }^{68} \mathrm{Ga}-\mathrm{DOTA}\right]-\mathrm{NOC}$ was injected. The scan, performed at 140 min p.i., revealed very intense uptake $\left(\mathrm{SUV}_{\max } 152\right)$ in a left retrocrural lymph node metastasis (Fig. 3a) as well as in a para- pancreatic lymph node (SUV 9.2) and in a very small lesion near the processus uncinatus of the pancreas (SUV 6.8). In addition, a small $(10 \mathrm{~mm})$ liver metastasis in the right inferior liver segment (S VI) was detected (SUV 11.6) (Fig. 3c), which had also been described in an MRI study.

The second PET/CT was performed 3 weeks later after i.v. injection of $130 \mathrm{MBq}$ of $\left[{ }^{68} \mathrm{Ga}\right.$-DOTA]-TATE, starting the acquisition $85 \mathrm{~min}$ p.i. Again, very high uptake $\left(\mathrm{SUV}_{\max } 103\right)$ was seen in the retrocrural metastasis (Fig. 3b), but no other lesions were detectable (Fig. 3c).

There was no increased glucose metabolism (normal $\left.\left[{ }^{18} \mathrm{~F}\right] \mathrm{FDG} \mathrm{PET} / \mathrm{CT}\right)$ in any of the lesions shown by the receptor PET/CT studies (Fig. 3d).

\section{Discussion}

The use of ${ }^{68} \mathrm{Ga}$ in nuclear oncology is becoming of increasing interest as it is a generator-produced, easily available positron emitter. ${ }^{68} \mathrm{Ga}$ has a physical half-life of $68 \mathrm{~min}$, which is compatible with the pharmacokinetics of most radiopharmaceuticals of low molecular weight such as antibody fragments, peptides, aptamers, oligonucleotides, etc. [37, 38]. ${ }^{68} \mathrm{Ga}$ decays to $89 \%$ by positron emission and to $11 \%$ via electron capture. The parent isotope ${ }^{68} \mathrm{Ge}$ has a very long half-life of 270.8 days, which allows routine manufacture and shipment, while the 
chemical properties of $\mathrm{Ge}(\mathrm{IV})$ and $\mathrm{Ga}(\mathrm{III})$ are sufficiently different to allow several different methods of efficient separation.

A particularly fascinating group of ${ }^{68} \mathrm{Ga}$-based radiopharmaceuticals are chelator-modified regulatory peptides that, owing to their small size, have ideal pharmacokinetics compatible with the short-lived ${ }^{68} \mathrm{Ga}$. Particularly somato- statin derivatives such as $\left[{ }^{\text {nat }} \mathrm{Ga}-\mathrm{DOTA}\right]-\mathrm{TOC}$ and $\left[{ }^{\text {nat }} \mathrm{Ga}\right.$ DOTA]-TATE show outstanding binding affinity to sst2 that is a factor of 4-8 higher compared with the corresponding yttrium or indium derivatives [5, 20, 35]. The higher binding affinity resulted in significantly higher tumour uptake in a tumour-bearing mouse model $[20,21]$. These positive preclinical results have prompted several
Fig. 3 Comparison between ${ }^{68}$ Ga-DOTA-NOC and ${ }^{68} \mathrm{Ga}-$ DOTA-TATE in the same patient (with a metastatic neuroendocrine pancreatic tumour), along with an $\left[{ }^{18} \mathrm{~F}\right]$ FDG PET/ CT scan. The first whole-body PET/CT study (Siemens biograph duo) was performed after i.v. injection of $85 \mathrm{MBq}{ }^{68} \mathrm{Ga}$ DOTA-NOC and revealed very intense uptake (SUV $\mathrm{Smax}_{\text {max }}$ of 152) in a left retrocrural lymph node metastasis (A. In addition, a liver metastasis (about $10 \mathrm{~mm}$ in diameter on MRI) in the right inferior liver segment (S VI) (SUV 11.6, C: a) and a very small parapancreatic lymph node metastasis $(\mathbf{C}: \mathbf{c})$ were detected. The second PET/CT scan was performed 3 weeks later after i.v. injection of $130 \mathrm{MBq}$ of ${ }^{68} \mathrm{Ga}$-DOTA-TATE. Again, very high uptake $\left(\mathrm{SUV}_{\max } 103\right)$ was seen in the retrocrural metastasis (B), but no other lesions were detectable $(\mathbf{C}: \mathbf{b}, \mathbf{d})$. There was no increased glucose metabolism (normal ${ }^{18}$ F-FDG PET/CT, D) in any of the lesions shown by receptor $\mathrm{PET} / \mathrm{CT}$ a

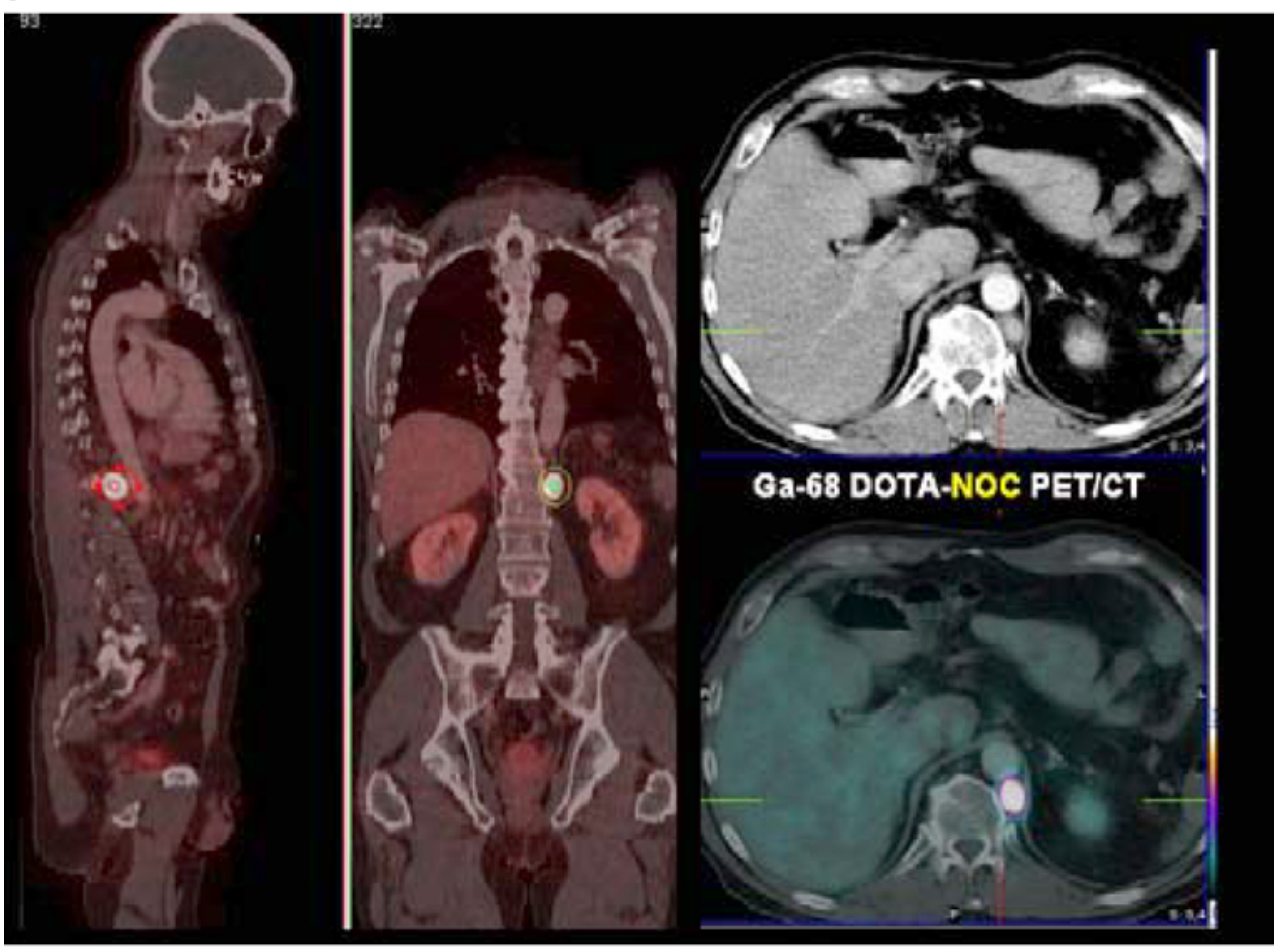

b

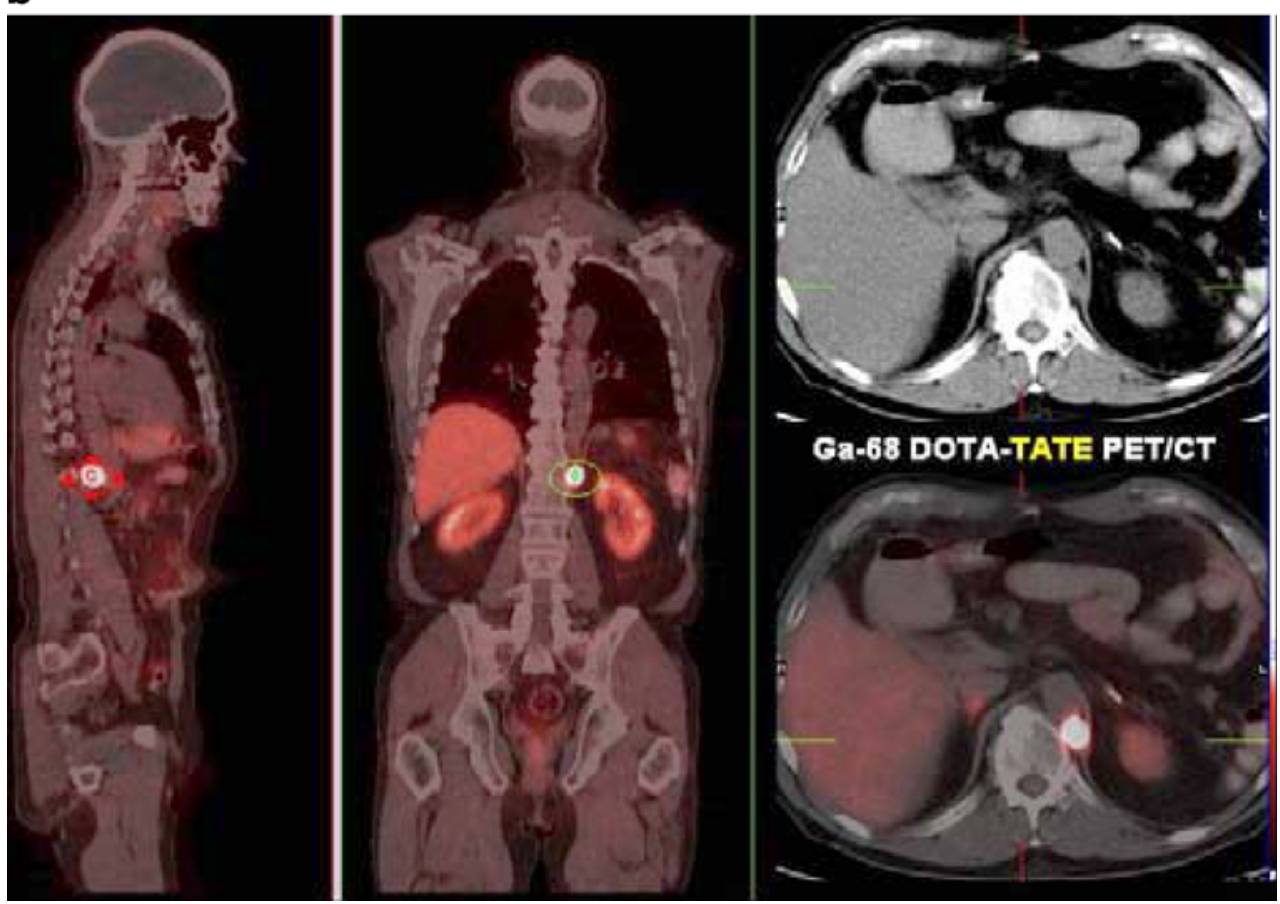


Fig. 3 (continued)

C

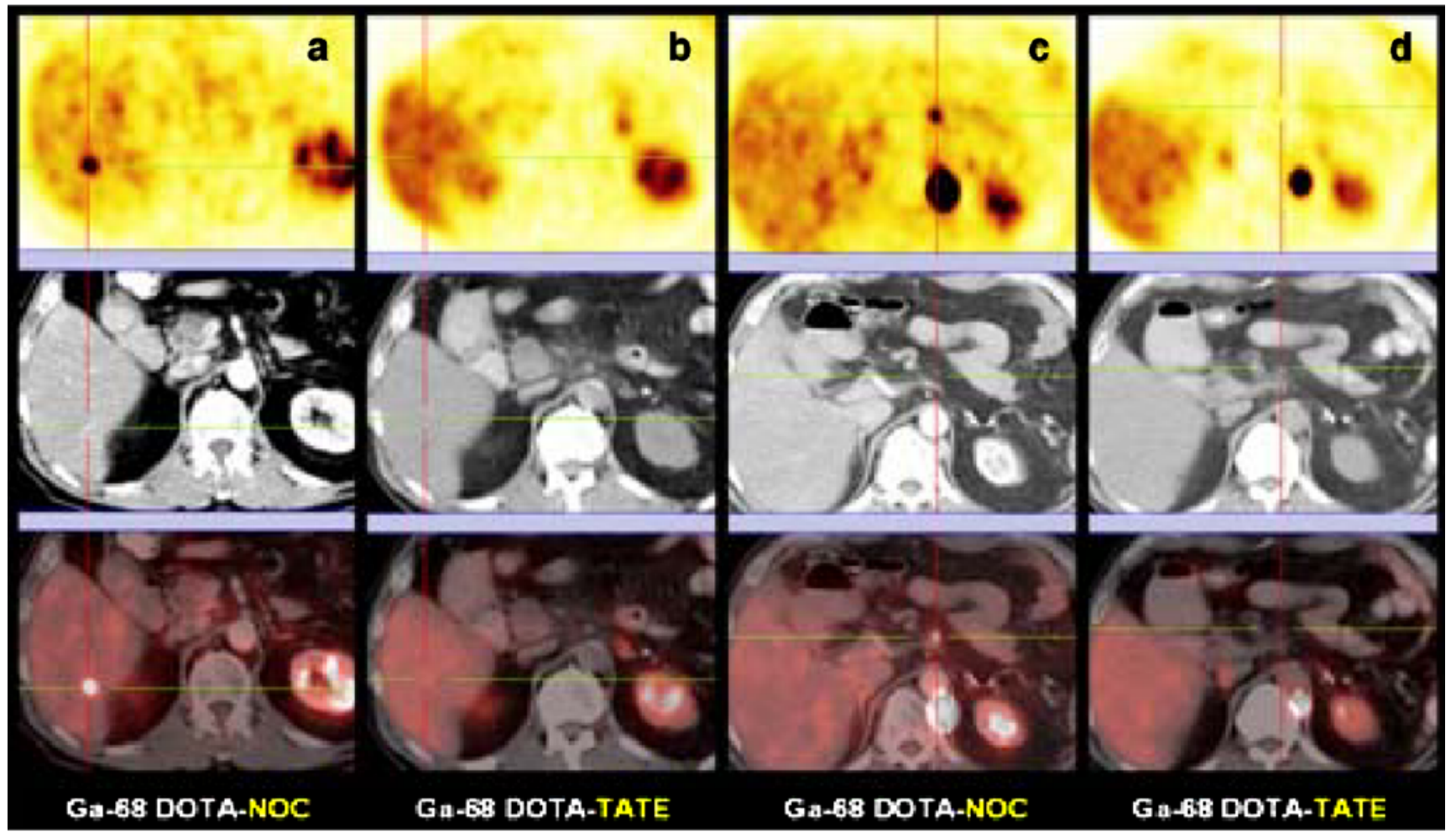

d

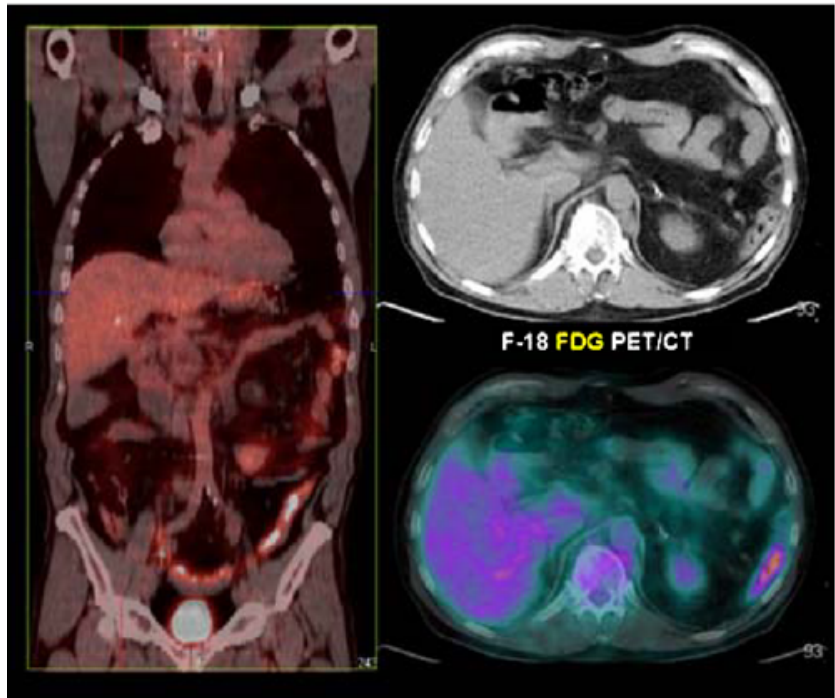

clinical groups to use $\left[{ }^{68} \mathrm{Ga}-\mathrm{DOTA}\right]-\mathrm{TOC}$ and $\left[{ }^{68} \mathrm{Ga}-\right.$ DOTA]-TATE in patient studies [22-27, 32].

We have recently reported that $\left[{ }^{111}\right.$ In-DOTA]-NOC may be a promising candidate for somatostatin receptor-positive tumour targeting because it recognises three somatostatin receptor subtypes with high affinity and may therefore target a broader range of tumours. Indeed, some preliminary results suggest that this new radiopeptide, if labelled with

${ }^{68} \mathrm{Ga}$, locates more metastases than the second-generation radiopeptides [30, 39-41], indicating that these new peptides are also pharmacologically superior compared with their ${ }^{111}$ In congeners. We designed a study to support these early clinical observations with firm preclinical pharmacological data using the ${ }^{68} \mathrm{Ga}$ congener, ${ }^{67} \mathrm{Ga}$.

A general trend was seen in regard to the binding affinity and the affinity profile of the $\mathrm{Ga}^{\mathrm{III}}$ vs $\mathrm{M}^{\mathrm{III}}$-DOTA-peptides 
$\left(\mathrm{M}^{\mathrm{III}}=\mathrm{In}^{\mathrm{III}}, \mathrm{Lu}^{\mathrm{III}}, \mathrm{Y}^{\mathrm{III}}\right)$. On hsst2, the binding affinities were significantly higher for the gallium-labelled peptides than for the $\mathrm{M}^{\mathrm{III}}$-DOTA-peptides $(p<0.0125)$. The difference was not significant for [Ga ${ }^{\text {III }}$-DOTA]-NOC-ATE vs [Y $\mathrm{Y}^{\mathrm{III}}$-DOTA]-NOC-ATE $(p>=0.124)$ but otherwise the $\mathrm{Ga}^{\mathrm{III}}$ derivatives had a two- to eightfold higher affinity.

On hsst3 there was a tendency in the opposite direction: the affinities of the $\mathrm{Ga}^{\mathrm{III}}$-complexed peptides were two- to fivefold lower. On hsst5 no clear tendency was obvious. None of the peptides has affinity to sst1 but surprisingly some emerging hsst 4 affinity can be seen, especially when complexed with $\mathrm{Ga}^{\mathrm{III}}$. We do not yet know which structural features are responsible for the latter.

A more striking advantage of the ${ }^{67}$ Ga-DOTA-peptides becomes evident upon studying the rate of internalisation into different cell lines. In sst2-expressing cells all ${ }^{67} \mathrm{Ga}$ labelled peptides showed high and specific internalisation with a significantly higher rate compared with the ${ }^{111} \mathrm{In}$ congeners. The difference between the two radionuclides became more striking when the internalisation was studied in HEK-sst2 cells, which express a higher number of receptors compared with AR4-2J cells.

In an earlier paper, Froidevaux et al. found no statistically significant difference between $\left[{ }^{67} \mathrm{Ga}-\mathrm{DOTA}\right]-$ TOC and $\left[{ }^{111}\right.$ In-DOTA]-TOC in AR4-2J cells [21]. The present data, however, showed a significant difference between the two radiopeptides. The internalisation into HEK-sst3 was comparatively low with no uptake of $\left[{ }^{67} \mathrm{Ga} /{ }^{111} \mathrm{In}\right.$-DOTA $]$-TOC, as expected, and paralleling the very low binding affinity of these two peptides to sst3. In contrast to the sst 2 data, the general tendency was for the ${ }^{111}$ In-labelled peptides to show more efficient internalisation into sst3, with the exception of $\left[{ }^{67} \mathrm{Ga}\right.$-DOTA]- and ${ }^{111}$ In-DOTA]-NOC, which internalised at an equal rate, not corresponding to the fivefold difference in binding affinity.

None of the radiopeptides internalises into sst5, which most likely is an intrinsic property of this receptor [42]. These in vitro pharmacological data indicate that $\left[{ }^{67} \mathrm{Ga}\right.$ DOTA]-BOC is the most promising radiopeptide to develop. However, as it showed some instability during labelling, we decided to study $\left[{ }^{67} \mathrm{Ga}-\mathrm{DOTA}\right]-\mathrm{NOC}$ in our tumour model. The analysis of the biodistribution at 4 and $24 \mathrm{~h}$ showed a significantly higher tumour uptake of $\left[{ }^{67} \mathrm{Ga}-\right.$ DOTA]-NOC compared with [ ${ }^{111}$ In-DOTA]-NOC. We hypothesise that the more rapid internalisation kinetics measured in vitro contributes to the increased in vivo uptake. We recently found that in a group of six somatostatin-based octapeptides labelled with ${ }^{99 \mathrm{~m}} \mathrm{Tc}$ and

${ }^{111}$ In, a good correlation indeed existed between tumour and pancreas uptake in vivo and the rate of internalisation into the AR4-2J cell line in vitro [4]. The uptake in other somatostatin receptor-positive tissues, such as the adrenals, the stomach and the bowel, follows this trend.
The potential of an imaging probe depends, among other parameters, on the target-to-non-target ratios, especially the tumour-to-blood ratio. All three radiopeptides showed a very high tumour-to-blood ratio, $\left[{ }^{67} \mathrm{Ga}\right.$-DOTA $]$-NOC having the highest among them. In addition, the tumour-tokidney ratio of 4.5 at $4 \mathrm{~h}$ and 5.1 at $24 \mathrm{~h}$ is, to the best of our knowledge, the highest of any radiometal-labelled peptide reported so far. On the other hand, the tumour-toliver ratio was clearly lowest for $\left[{ }^{67} \mathrm{Ga}-\mathrm{DOTA}\right]-\mathrm{NOC}$. This result was due to the almost fivefold higher liver uptake of $\left[{ }^{67} \mathrm{Ga}-\mathrm{DOTA}\right]-\mathrm{NOC}$ compared with that of $\left[{ }^{111} \mathrm{In}\right.$-DOTA $]-$ NOC, which is somewhat surprising considering the much lower $\log \mathrm{D}$ value (higher hydrophilicity; see Table 4) of $\left[{ }^{67} \mathrm{Ga}-\mathrm{DOTA}\right]-\mathrm{NOC}$ compared with $\left[{ }^{111} \mathrm{In}\right.$-DOTA $]$-NOC. It is currently unclear whether active mechanisms including organic anion transporters are involved in the increased liver uptake.

An interesting finding from this study is that the radiometal indeed influences the pharmacological properties of the radiopeptides; this earlier finding [21, 35] can be extended to the new generation of somatostatin-based radiopeptides. Labelling with ${ }^{67 / 68} \mathrm{Ga}$ results in peptides that are superior to those labelled with ${ }^{111} \mathrm{In},{ }^{90} \mathrm{Y}$ or ${ }^{177} \mathrm{Lu}$. We have explained this difference by a difference in the coordination number and geometry of the various radiometal complexes [20]. The model peptide Ga ${ }^{\mathrm{III}}$-DOTA-D$\mathrm{PheNH}_{2}$ showed a cis-pseudo-octahedral geometry without the coordination of the amide linkage and the corresponding trans carboxy methyl group, whereas the $\mathrm{Y}^{\mathrm{III}}$ complex is octacoordinate including the amide carboxy oxygen and the carboxymethyl group. The complex geometry is a somewhat distorted square antiprism [20]. The non-involved amide linkage of the $\mathrm{Ga}^{\mathrm{III}}$ complex consequently offers more flexibility, the free arm acting as a spacer between peptide and chelate. This may lead to the higher binding affinity on hsst 2 whereas the free carboxylate group may favour kidney excretion.

In summary, these data suggest that most, if not all, ${ }^{68}$ Ga-labelled second- and third-generation somatostatinbased radiopeptides show superior properties in imaging somatostatin receptor-positive tumours compared with firstgeneration somatostatin-based radiopeptides. This is due to superior pharmacological properties on hsst2, which is the most densely and frequently expressed receptor subtype. Despite some loss in hsst3 and hsst5 affinity, the radio-

Table $4 \log \mathrm{D}$ at $\mathrm{pH}=7.4$ of radiolabelled conjugates

\begin{tabular}{ll}
\hline Compound name & $\log \mathrm{D}(\mathrm{pH}=7.4)$ \\
\hline$\left[{ }^{67} \mathrm{Ga}-\mathrm{DOTA}\right]-\mathrm{NOC}$ & $-2.88 \pm 0.12$ \\
{$\left[{ }^{111} \mathrm{In}-\mathrm{DOTA}\right]-\mathrm{NOC}$} & $-2.06 \pm 0.20$ \\
\hline
\end{tabular}


gallium-labelled peptides still show a broad hsst profile. Given the higher sensitivity of the PET technique, $\left[{ }^{68} \mathrm{Ga}-\right.$ DOTA $]$-NOC and $\left[{ }^{68} \mathrm{Ga}-\mathrm{DOTA}\right]-\mathrm{BOC}$ should also be further developed into new PET tracers for extended clinical studies.

The intra-individual comparison of $\left[{ }^{68} \mathrm{Ga}\right.$-DOTA $]$-NOC and $\left[{ }^{68} \mathrm{Ga}\right.$-DOTA]-TATE (Fig. 3a-c) in a patient with metastases of a neuroendocrine pancreatic carcinoma demonstrated that the broader somatostatin receptor subtype profile of $\left[{ }^{68} \mathrm{Ga}\right.$-DOTA]-NOC (sst2, 3 and 5 affinity) and internalisation may be of clinical relevance as a significantly higher uptake of this radiopeptide was found

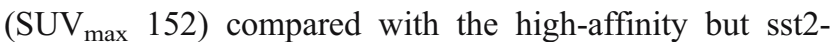
selective radiopeptide $\left[{ }^{68} \mathrm{Ga}\right.$-DOTA]-TATE $\left(\mathrm{SUV}_{\max } 103\right)$. In addition, very small lesions were detected when using $\left[{ }^{68} \mathrm{Ga}\right.$-DOTA $]$-NOC as compared to $\left[{ }^{68} \mathrm{Ga}\right.$-DOTA $]$-TATE. Along with the ${ }^{68} \mathrm{Ge} /{ }^{68} \mathrm{Ga}$ generator, these tracers may be very cost effective, sensitive and readily available imaging agents. Furthermore, they cause low radiation doses to patients compared with existing tracers and their ${ }^{111} \mathrm{In}$ labelled congeners [31]. Along with ${ }^{64} \mathrm{Cu}$-labelled radiopharmaceuticals [43-45], ${ }^{68}$ Ga-labelled compounds are a fast-growing area of research which benefits from the availability of a commercial generator.

Acknowledgements P. Antunes acknowledges the PhD Fellowship of the Fundação para a Ciência e Tecnologia (Ref. SFRH/BD/3136/ 2000). In addition, P. Antunes, M. Ginj, M. Walter and H. Maecke acknowledge the support from the Swiss National Science Foundation project No. 3100A0-100390, BBW project No C00.0091, and the network of excellence, European Molecular Imaging Laboratories (EMIL). The support provided by Novartis Pharma in respect of ESIMS analysis is gratefully acknowledged. We thank Dr. S. Schulz for the sst3-transfected human embryonic kidney 293 cells. The authors thank K. Hinni and S. Tschumi for biological technical assistance. This work was performed within the COST B12 Action.

\section{References}

1. Reubi JC. Peptide receptors as molecular targets for cancer diagnosis and therapy. Endocr Rev 2003;24:389-427.

2. Maina T, Nock B, Nikolopoulou A, Sotiriou P, Loudos G, Maintas $\mathrm{D}$, et al. $\left[{ }^{99 \mathrm{~m}} \mathrm{Tc}\right]$ Demotate, a new ${ }^{99 \mathrm{~m}} \mathrm{Tc}$-based $\left[\mathrm{Tyr}^{3}\right]$ octreotate analogue for the detection of somatostatin receptor-positive tumours: synthesis and preclinical results. Eur J Nucl Med Mol Imaging 2002;29:742-53.

3. Decristoforo C, Mather SJ, Cholewinski W, Donnemiller E, Riccabona G, Moncayo R. ${ }^{99 m}$ Tc-EDDA/HYNIC-TOC: a new ${ }^{99 \mathrm{~m}} \mathrm{Tc}$-labelled radiopharmaceutical for imaging somatostatin receptor-positive tumours; first clinical results and intra-patient comparison with ${ }^{111}$ In-labelled octreotide derivatives. Eur J Nucl Med 2000;27:1318-25.

4. Storch D, Behe M, Walter MA, Chen J, Powell P, Mikolajczak R, et al. Evaluation of $\left.{ }^{99 \mathrm{~m}} \mathrm{Tc} / \mathrm{EDDA} / \mathrm{HYNIC}^{0}\right]$ octreotide derivatives compared with $\left[{ }^{111} \mathrm{In}-\mathrm{DOTA}{ }^{0}, \mathrm{Tyr}^{3}, \mathrm{Thr}^{8}\right]$ octreotide and $\left[{ }^{111} \mathrm{In}\right.$ DTPA $^{0}$ ]octreotide: does tumor or pancreas uptake correlate with the rate of internalization? J Nucl Med 2005;46:1561-9.
5. de Jong M, Bakker WH, Krenning EP, Breeman WA, van der Pluijm ME, Bernard BF, et al. Yttrium-90 and indium-111 labelling, receptor binding and biodistribution of $\left[\mathrm{DOTA}^{0}, \mathrm{D}-\right.$ $\mathrm{Phe}^{1}, \mathrm{Tyr}^{3}$ ]octreotide, a promising somatostatin analogue for radionuclide therapy. Eur J Nucl Med 1997;24:368-71.

6. Krenning EP, Kwekkeboom DJ, Bakker WH, Breeman WA, Kooij PP, Oei HY, et al. Somatostatin receptor scintigraphy

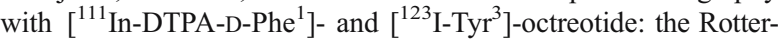
dam experience with more than 1000 patients. Eur J Nucl Med 1993;20:716-31.

7. Smith-Jones PM, Stolz B, Bruns C, Albert R, Reist HW, Fridrich $\mathrm{R}$, et al. Gallium-67/gallium-68-[DFO]-octreotide - a potential radiopharmaceutical for PET imaging of somatostatin receptorpositive tumors: synthesis and radiolabeling in vitro and preliminary in vivo studies. J Nucl Med 1994;35:317-25.

8. Henriksen G, Schottelius M, Poethko T, Hauser A, Wolf I, Schwaiger M, et al. Proof of principle for the use of ${ }^{11} \mathrm{C}$-labelled peptides in tumour diagnosis with PET. Eur J Nucl Med Mol Imaging 2004;31:1653-7.

9. Wester H-J, Schottelius M, Scheidhauer K, Meisetschläger G, Herz M, Rau F, et al. PET imaging of somatostatin receptors: design, synthesis and preclinical evaluation of a novel ${ }^{18} \mathrm{~F}$ labelled, carbohydrated analogue of octreotide. Eur J Nucl Med Mol Imaging 2002;30:117-22.

10. Sprague JE, Peng Y, Sun X, Weisman GR, Wong EH, Achilefu S, et al. Preparation and biological evaluation of copper-64-labeled $\mathrm{Tyr}^{3}$-octreotate using a cross-bridged macrocyclic chelator. Clin Cancer Res 2004;10:8674-82.

11. Waldherr C, Pless M, Maecke H, Schumacher T, Crazzolara A, Nitzsche E, et al. Tumor response and clincical benefit in neuroendocrine tumors after $7.4 \mathrm{GBq}{ }^{90}$ Y-DOTATOC. J Nucl Med 2002;43:610-6.

12. Otte A, Mueller-Brand J, Dellas S, Nitzsche E, Herrmann R, Maecke H. Yttrium-90-labelled somatostatin-analogue for cancer treatment. Lancet 1998;351:417-8.

13. Kwekkeboom DJ, Mueller-Brand J, Paganelli G, Anthony LB, Pauwels S, Kvols LK, et al. Overview of results of peptide receptor radionuclide therapy with 3 radiolabeled somatostatin analogs. J Nucl Med 2005;46:62S-66S.

14. Bodei L, Cremonesi M, Zoboli S, Grana C, Bartolomei M, Rocca $\mathrm{P}$, et al. Receptor-mediated radionuclide therapy with ${ }^{90} \mathrm{Y}-$ DOTATOC in association with amino acid infusion: a phase I study. Eur J Nucl Med 2003;30:207-16.

15. de Jong M, Breeman WA, Bernard BF, Bakker WH, Schaar M, van Gameren A, et al. $\left[{ }^{177} \mathrm{Lu}_{-\mathrm{DOTA}}{ }^{0}, \mathrm{Tyr}^{3}\right]$ octreotate for somatostatin receptor-targeted radionuclide therapy. Int $\mathrm{J}$ Cancer 2001;92:628-33.

16. Norenberg JP, Krenning BJ, Konings IR, Kusewitt DF, Nayak TK, Anderson TL, et al. ${ }^{213} \mathrm{Bi}-\left[\mathrm{DOTA}^{0}, \mathrm{Tyr}^{3}\right]$ octreotide peptide receptor radionuclide therapy of pancreatic tumors in a preclinical animal model. Clin Cancer Res 2006;12:897-903.

17. Jensen RT. Carcinoid and pancreatic endocrine tumors: recent advances in molecular pathogenesis, localization, and treatment. Curr Opin Oncol 2000;12:368-77.

18. Maecke HR, Hofmann M, Haberkorn U. ${ }^{68}$ Ga-labeled peptides in tumor imaging. J Nucl Med 2005;46:172S-8S.

19. Eisenwiener KP, Prata MI, Buschmann I, Zhang HW, Santos AC, Wenger $\mathrm{S}$, et al. NODAGATOC, a new chelator-coupled somatostatin analogue labeled with $\left[{ }^{67 / 68} \mathrm{Ga}\right]$ and $\left[{ }^{111} \mathrm{In}\right]$ for SPECT, PET, and targeted therapeutic applications of somatostatin receptor (hsst2) expressing tumors. Bioconjug Chem 2002;13:530-41.

20. Heppeler A, Froidevaux S, Mäcke HR, Jermann E, Béhé M, Powell $\mathrm{P}$, et al. Radiometal-labelled macrocyclic chelatorderivatised somatostatin analogue with superb tumour-targeting properties and potential for receptor-mediated internal radiotherapy. Chemistry A European Journal 1999;5:1016-23. 
21. Froidevaux S, Eberle AN, Christe M, Sumanovski L, Heppeler A, Schmitt JS, et al. Neuroendocrine tumor targeting: study of novel gallium-labeled somatostatin radiopeptides in a rat pancreatic tumor model. Int J Cancer 2002;98:930-7.

22. Hofmann M, Maecke H, Börner A, Weckesser E, Schöffski P, Oei $\mathrm{M}$, et al. Biokinetics and imaging with the somatostatin receptor PET radioligand ${ }^{68} \mathrm{Ga}$-DOTATOC: preliminary data. Eur J Nucl Med 2001;28:1751-7.

23. Kowalski J, Henze M, Schuhmacher J, Maecke HR, Hofmann M, Haberkorn U. Evaluation of positron emission tomography imaging using $\left[{ }^{68} \mathrm{Ga}\right]$-DOTA-D Phe ${ }^{1}-\mathrm{Tyr}^{3}$-octreotide in comparison to $\left[{ }^{111} \mathrm{In}\right]$-DTPAOC SPECT. First results in patients with neuroendocrine tumors. Mol Imaging Biol 2003;5:42-8.

24. Henze M, Dimitrakopoulou-Strauss A, Milker-Zabel S, Schuhmacher J, Strauss LG, Doll J, et al. Characterization of ${ }^{68}$ Ga-DOTA-D-Phe ${ }^{1}$-Tyr ${ }^{3}$-octreotide kinetics in patients with meningiomas. J Nucl Med 2005;46:763-9.

25. Henze M, Schuhmacher J, Dimitrakopoulou-Strauss A, Strauss LG, Maecke HR, Eisenhut M, et al. Exceptional increase in somatostatin receptor expression in pancreatic neuroendocrine tumour, visualised with ${ }^{68} \mathrm{Ga}$-DOTATOC PET. Eur J Nucl Med Mol Imaging 2004;31:466.

26. Henze M, Schumacher T, Hipp P, Kowalski J, Becker D, Doll J, et al. PET imaging of somatostatin receptors using $\left[{ }^{68} \mathrm{Ga}\right] \mathrm{DOTA}-\mathrm{D}-$ $\mathrm{Phe}^{1}-\mathrm{Tyr}^{3}$-octreotide: first results in patients with meningiomas. J Nucl Med 2001;42:1053-6.

27. Dimitrakopoulou-Strauss A, Georgoulias V, Eisenhut M, Herth F, Koukouraki S, Macke HR, et al. Quantitative assessment of SSTR2 expression in patients with non-small cell lung cancer using ${ }^{68}$ Ga-DOTATOC PET and comparison with ${ }^{18}$ F-FDG PET. Eur J Nucl Med Mol Imaging 2006;33:823-30.

28. Baum R, Niesen A, Leonhardi J, Wortmann R, Mueller D, Roesch F. Receptor PET/CT imaging of neuroendocrine tumours using the Ga-68 labelled, high affinity somatostatin analogue DOTA-1$\mathrm{Nal}^{3}$ octreotide (DOTA-NOC): clinical results in 327 patients. Eur J Nucl Med Mol Imaging 2005;32 Suppl 1:S54-5.

29. Roesch F, Zhernosekov K, Filosofov D, Jahn M, Jennewein M, Baum R, et al. Processing of Ge-68/Ga-68 generator eluates for labeling of biomolecules via bifunctional chelators. J Nucl Med 2006;47 Suppl 1:162P.

30. Baum R, Schmücking M, Wortmann R, Müller M, Zhernosekov K, Rösch F. Receptor PET/CT using the Ga-68 labelled somatostatin analog DOTA-1-Nal ${ }^{3}$-octreotide (DOTA-NOC): clinical experience in 140 patients. Nuklearmedizin 2005;44:A57.

31. Rufini V, Calcagni ML, Baum RP. Imaging of neuroendocrine tumors. Semin Nucl Med 2006;36:228-47.

32. Win Z, Rahman L, Murrell J, Todd J, Al-Nahhas A. The possible role of ${ }^{68} \mathrm{Ga}$-DOTATATE PET in malignant abdominal paraganglioma. Eur J Nucl Med Mol Imaging 2006;33:506.
33. Wild D, Schmitt JS, Ginj M, Maecke HR, Bernard BF, Krenning E, et al. DOTA-NOC, a high-affinity ligand of somatostatin receptor subtypes 2, 3 and 5 for labelling with various radiometals. Eur J Nucl Med Mol Imaging 2003;30:1338-47.

34. Ginj M, Chen J, Walter MA, Eltschinger V, Reubi JC, Maecke HR. Preclinical evaluation of new and highly potent analogues of octreotide for predictive imaging and targeted radiotherapy. Clin Cancer Res 2005;11:1136-45.

35. Reubi JC, Schar JC, Waser B, Wenger S, Heppeler A, Schmitt JS, et al. Affinity profiles for human somatostatin receptor subtypes SST1-SST5 of somatostatin radiotracers selected for scintigraphic and radiotherapeutic use. Eur J Nucl Med 2000;27: 273-82.

36. Tulipano G, Stumm R, Pfeiffer M, Kreienkamp HJ, Hollt V, Schulz S. Differential $\beta$-arrestin trafficking and endosomal sorting of somatostatin receptor subtypes. J Biol Chem 2004;279:2137482.

37. Smith-Jones PM, Solit DB, Akhurst T, Afroze F, Rosen N, Larson SM. Imaging the pharmacodynamics of HER2 degradation in response to Hsp90 inhibitors. Nat Biotechnol 2004;22:701-6.

38. Smith-Jones PM, Solit D, Afroze F, Rosen N, Larson SM. Early tumor response to Hsp90 therapy using HER2 PET: comparison with ${ }^{18}$ F-FDG PET. J Nucl Med 2006;47:793-6.

39. Wild D, Maecke HR, Waser B, Reubi JC, Ginj M, Rasch H, et al. ${ }^{68}$ Ga-DOTANOC: a first compound for PET imaging with high affinity for somatostatin receptor subtypes 2 and 5. Eur J Nucl Med Mol Imaging 2004;32:724.

40. Decristoforo C, von Guggenberg E, Haubner R, Rupprich M, Schwarz S, Virgolini I. Radiolabeling of DOTA-derivatised peptides with ${ }^{68} \mathrm{Ga}$ via a direct approach-optimization and routine clinical application. Nuklearmedizin 2005;44:A191-2.

41. Hofmann M, Oei M, Boerner AR, Maecke H, Geworski L, Knapp WH, et al. Comparison of Ga-68-DOTATOC and Ga68-DOTANOC for radiopeptide PET. Nuklearmedizin 2005;44: A58.

42. Cescato R, Schulz S, Waser B, Eltschinger V, Rivier JE, Wester $\mathrm{HJ}$, et al. Internalization of sst2, sst3, and sst5 receptors: effects of somatostatin agonists and antagonists. J Nucl Med 2006;47: 502-11.

43. Smith SV. Molecular imaging with copper-64. J Inorg Biochem 2004;98:1874-901.

44. Rossin R, Pan D, Qi K, Turner JL, Sun X, Wooley KL, et al. ${ }^{64} \mathrm{Cu}$-labeled folate-conjugated shell cross-linked nanoparticles for tumor imaging and radiotherapy: synthesis, radiolabeling, and biologic evaluation. J Nucl Med 2005;46:1210-8.

45. Boswell CA, Sun X, Niu W, Weisman GR, Wong EH, Rheingold $\mathrm{AL}$, et al. Comparative in vivo stability of copper-64-labeled cross-bridged and conventional tetraazamacrocyclic complexes. J Med Chem 2004;47:1465-74. 